\title{
Effectiveness testing of reporting systems and organizational responses toward whistleblowing intentions
}

Frandyo Izak Muskita

Faculty of Economics and Business, Universitas Kristen Satya Wacana, Salatiga, Indonesia

Intiyas Utami

Faculty of Economics and Business, Universitas Kristen Satya Wacana, Salatiga, Indonesia

Aprina Nugrahesthy Sulistya Hapsari

Faculty of Economics and Business, Universitas Kristen Satya Wacana, Salatiga, Indonesia aprina@uksw.edu

Follow this and additional works at: https://journal.uii.ac.id/jca

Copyright (C2019 Journal of Contemporary Accounting and Authors.

To cite this article: Frandyo Izak Muskita, Intiyas Utami, Aprina Nugrahesthy Sulistya Hapsari. (2019). Effectiveness testing of reporting systems and organizational responses toward whistleblowing intentions. Journal of Contemporary Accounting, 1(3), 131-144. doi:10.20885/jca.vol1.iss3.art1 


\title{
Effectiveness testing of reporting systems and organizational responses toward whistleblowing intentions
}

\author{
Frandyo Izak Muskita ${ }^{1}$, Intiyas Utami ${ }^{2}$, Aprina Nugrahesthy Sulistya Hapsari ${ }^{3}$ \\ 1,2,3 Faculty of Economics and Business, Universitas Kristen Satya Wacana, Salatiga, Indonesia
}

JEL Classification:

M40, D73

\section{Keywords:}

reporting system, organizational responses, whistleblowing intentions.

\section{Corresponding Author:}

aprina@uksw.edu

DOI:

10.20885/jca.vol1.iss3.art1

Copyright (C2019

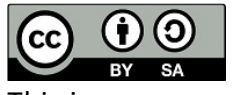

This is an open access under CC-BY-SA LICENSE

\begin{abstract}
Whistleblowing is disclosure of individual or organizational frauds committed by members of an organization. Reporting and response system in organizations are related to whistleblowing intentions and they are considered by whistleblowers to conduct whistleblowing action. This study was conducted to examine the causality relationship between the reporting systems and the organizational responses with whistleblowing intentions. This study was conducted as a laboratorial study at two universities in Central Java with 88 students in Accounting major as respondents in this study of which this study produced 73 data that are ready to use. The study uses $2 \times 2$ between subjects design and manipulates the reporting systems and organizational responses. The result showed that subjects who used an online reporting system and received a response system of whistleblower tended to have higher intentions in carrying out whistleblowing. On the other hand, subjects who used an offline reporting system and who did not received a response system of whistleblower tended to be lower in their intentions to do whistleblowing.
\end{abstract}

\section{Introduction}

A fraud often occurs in the operations of an organizational entity, it may come from inside or outside of an organization. Frauds can be mitigated by whistleblowing, which is a reporting system that involves all levels of staffs and employees in a company after the company believes that the system has been well socialized in the company (Zarefar \& Arfan, 2017). In general whistleblowing in organizations are done by internal and external auditors as well as by policy makers (Putri, 2012), however, there is no guarantee that frauds can be detected through the applied systems.

Fraud in financial reports is an abuse of authority committed to financial reporting which is usually carried out by management (Sunaryo, Astuti, \& Zuhrohtun, 2019). Whistleblowing proved to be quite effective in revealing the existence of frauds in several cases. Worldcom is the second largest and trusted telecommunication company in the United States. However, Worldcom began to decline at the beginning of the $21^{\text {st }}$ century that had prompted CFO and senior auditors to change the company's financial statement. This inappropriate financial statement has aroused suspicion by several employees of the company. The suspicion grew even more when CFO of Worldcom gave an order for one of its employees not to tell the truth. Finally, through this suspicion, they worked together and tried to audit the company's financial statement. In May 2002, they managed to find anomaly in the company's financial statement which then it forced the Worldcom to declare its bankruptcy.

In addition to these cases, there are also cases that occur in Indonesia, such as the case of Susno Duaji who revealed the existence of a tax mafia in his institution. This case involved Gayus Tambunan, a staff of the Directorate General of Taxes. This case reveals the corruption in an effort 
to free Susno Duaji from money laundering charges. Other cases in Indonesia are the case involving Agus Condro in the selection of Senior Deputy of Indonesian Central Bank and the case of Yohanes Wowuruntu related to the Legal Entity Administration System. These cases show the importance of response that must be given to the reporter of frauds to improve the effectiveness of whistleblowing. The Sarbanes-Oxley Act 2002, Sections $301 \& 806$, is specifically designed to encourage whistleblowing and provide responses for employees who report irregularities regarding frauds in accounting or auditing. This regulation is very essential because the reality shows that frauds are revealed by employees and not by auditors as authorities.

An effective whistleblowing system is a system that contains five aspects, namely, human and ethical culture, policy, legal protection, organizational structure and processes and procedures (Nurhidayat \& Kusumasari, 2018). Nowadays, there are a number of government and private organizations implementing whistleblowing reporting systems. In Indonesia, the Corruption Eradication Commission (KPK) has developed an internet-based complaint reporting system called KPK-Whistleblower System. Government agencies such as LKPP have also implemented systems of procurement of goods and services or known as WBS-Government. It aims to facilitate complaints about the procurement of goods and services within government agencies. The identification of the implementation of the whistleblowing system within the Indonesian ministry which was carried out in 21 Indonesian ministries referring to the $2008 \mathrm{KNKG}$ module showed that $19.84 \%$ of the Indonesian ministries had implemented a whistleblowing system in accordance with the 2008 KNKG module (Arismaya \& Utami, 2019).

A good reporting system is a system that can be easily accessed and be able to keep secret the identity of whistleblowers (Near \& Miceli, 1995). The whistleblowing reporting system is classified into online and offline reporting systems. The online reporting system is easy to use and fast to be used to report frauds, because it takes advantages of hotline services. Hotline service will allow reporting of frauds anonymously, which it anonymous reporting can helps reducing perceived risk of retaliation as a consequence of whistleblowing action done by whistleblowers. Meanwhile, offline reporting system takes a lot of time because it has to follow the existing structure and whistleblowers must hold a meeting in order to explain the frauds that they find in an organization. Many people will do whistleblowing if they consider that the potential threats are high and if there is not a guarantee of safety for them and their families. Therefore regulations to protect whistleblowers must be made and there must be a response and fairness from organizations.

Dozier and Miceli (1985) asserted that organizational response through whistleblower's view is the most important factor in decision making when conducting a whistleblowing. The response given is in the form of incentives and guarantees that the company will support ethical behaviors that will lead to the perception of whistleblowers that the submitted report will produce a resolution. However, the main factor in the decision for whistleblowing is the expectation that the report will stop activities that may harm an organization (Salsabil, Utami, \& Hapsari, 2019).

Kaplan and Schultz (2007) tested the effectiveness of anonymous reporting channels to encourage individuals to report fraud. This type of reporting is still effective in encouraging people to report wrongdoings in their company (Lowry, Moody, Galletta, \& Vance, 2013), while Sagara (2013) found that whistleblowing reporting by internal auditors through their professionalism side in terms of their independence will not necessarily be done anonymously. The purpose of this study is to examine the causality relationship between anonymous online and offline whistleblowing reporting systems and organizational responses toward whistleblowers in the condition of there is a respond or there is no respond from an organization toward the intention to do whistleblowing. The materials in this study are expected to be considered in implementing protection for whistleblowers, which distinguishes this study from previous studies related to variables of organizational responses to whistleblowing actions. It is hoped that this study can provide empirical evidences that whistleblowing reporting systems and organizational responses are needed to encourage whistleblowing intentions when fraud occurs in organizations. 


\section{Literature Review}

\section{The Theory of Pro-Social Organizational Behavior}

One of theories that support whistleblowing is the Theory of Pro-social Organizational Behavior. Brief and Motowidlo (1986) defines pro-social organizational behavior as a behavior or an action taken by members of an organization against individuals, groups, or organizations aimed at improving the welfare of individuals, groups, or organizations. The pro-social behavior is seen when members of an organization express their opposition to the existence of procedures or policies that according to them as are unethical for the organization, but they cannot instantly show these errors and thus they take a whistleblowing action and submit the matter to those who have authority in the organization.

\section{Whistleblowing}

Whistleblowing can be understood as a reporting system from employees who report to internal or external parties about illegal practices in their work environment and expect for a response from the company in form of follow-up action for the related illegal practices. Keenan (1990)revealed that whistleblowing is a report by member(s) of an organization regarding unscrupulous practices without the knowledge of the leadership to those who have authority in the organization that can result corrective actions. People who report frauds are called whistleblowers. The important thing to become a whistleblower is the existence of clear indications and information on violations to be reported so that these violations can then be followed up by the authorities (Lestari \& Yaya, 2017).

AICPA (2007) explains that a functioning whistleblowing system is in a form of channel where employees feel safe to report errors and one of ways for the safe feeling can be realized is through an anonymous reporting in the whistleblowing process. In fact, there are obstacles in whistleblowing by using of a channel that exposes the identities of reporters due to retaliation that may be suffered by the reporters of frauds (Utami, Jori, \& Hapsari, 2017). An anonymous whistleblowing reporting system is effective for employees to report violations. Therefore, the main part of the whistleblowing system is anonymity that gives secrecy and integrity for whistleblowers so that they will consider that it is secure and safe to inform any errors that they find (Widi \& Utami, 2015).

\section{Organizational Response Toward Whistleblowers}

Whistleblowers come from internal parties within an organization itself from or external parties (customers, suppliers, and the public) who provide reports and who have clear evidences of violations of which the violations or fraud practices within the organization can be eradicated (Sagara, 2013). Whistleblowers sometimes also consider the response from their organization. Taylor and Curtis (2013) explain that the response from an organization will encourage whistleblowers' courage to conduct a whistleblowing because there are guarantees for their safety through confidentiality of identities or through legal protections.

A good fraud reporting system can provide responses and facilities to whistleblowers, including reporting channel facilities (telephone, letter, E-mail), protection against retaliation or pressure, postponement of promotion, dismissal, legal action, and physical action against reporters. The protection for reporters in a good reporting system is very essential because comfort and security are important factors in work places (Setyawati, Ardiyani, \& Sutrisno, 2015). Guarantees for whistleblowers can also be received through legal protection by lawyers, though this type of protections can cost a lot of money for reporters to pay lawyers.

Whistleblowers usually report frauds in an effort to end them (Near \& Miceli, 2016). In addition, whistleblowers must also have courage and confidence because their actions are indeed risky for them. There are so many risks that must be faced by whistleblowers especially related to 
their personal lives and works. It is not uncommon for whistleblowers to receive threats and terrors of murder from people who are being reported (Hanif \& Odiatma, 2017). Thus whistleblowers need an organizational response so that they will feel safe and can realize their intention to report frauds.

\section{Whistleblowing Intention}

In conducting whistleblowing, one must first have a strong intention because whistleblowing is not easy to do. It is because whistleblowers may have to bear risks to their career and their safety. The intention of whistleblowing can be strengthened by the response and guarantee from an organization for whistleblowers. Chiu (2003) considers that the whistleblowing system is very effective in exposing fraud but a whistleblower must have courage and personal intention and consider the guarantees given by his organization in form of support from supervisors, informal policies, open door system, reward systems, telephone hotlines, and formal-confidential disclosure procedures.

Whistleblowing is a reliable monitoring tool to detect potential frauds (Alleyne, Hudaib, \& Pike, 2013). The intention of whistleblowing refers to one's ability to judge whether other person behaviors as right or wrong ( $\mathrm{Li}, \mathrm{Zhu}, \&$ Gummerum, 2014). Someone who knows and wants to reveal the occurring frauds certainly has a positive impact to his organization and external parties. Near and Miceli (2016) revealed that on average whistleblowers are more comfortable to report frauds internally rather than externally. By reporting internally in advance, an organization can take corrective actions to eradicate frauds.

\section{The Relationship of Reporting Channel and Whistleblowing Intentions}

Reporting channel are designed for various types of fraud including frauds in organizations. The reporting channel can be divided into online and offline. The online channel is a reporting system that can help disguise the whistleblower's identity. The online chainnel allows anonymous systems to be implemented. The presence of anonymous internal reporting channels affects one's intention to report frauds using one of two non-anonymous internal reporting channels, i.e., to management or the internal audit department. Ayers and Kaplan (2005) explained that the perceived costs and benefits of anonymous and non-anonymous reporting channels are still limited. Until now, it has not been well known about whether the availability of anonymous reporting channels systematically influences one's reporting intentions compared to non-anonymous reporting channels. The disclosure of complaints is received anonymously, where the complainant does not provide his identity at all. Brink et al., (2013) explained that employees' preference for internal reporting due to intrinsic motivations may be crowded-out when an internal reward is introduced. Further, an internal reward may re-frame internal reporting as a self-interested action blurring the distinction between external and internal reporting from an ethical perspective.

Smith et al., (2001) identified reporting anonymity as a key factor that could affect whistleblowing intentions. Kaplan and Schultz (2007) explained that from an organizational perspective, an anonymous internal reporting system is a good system, they also find that the existence of an anonymous channel reduces the likelihood of reporting to non-anonymous channels. Anonymous reporting systems offer opportunities to improve the integrity of reporting and to enable an effective reporting system for reporting frauds within an organization (Salsabil et al., 2019), by doing so, the reporting systems in an organization can guarantee the confidentiality of fraud reporters. Kaplan and Schultz (2007) stated that a good reporting system is the anonymous reporting system so that the intention of whistleblowers will be higher in anonymous reporting systems than in non-anonymous systems. Thus, first hypothesis can be formulated as follows:

$\mathbf{H}_{1}$ : Subjects that use online reporting system will have a higher whistleblowing intention than subjects that use offline reporting system. 


\section{The Relationship Between Organizational Responses and Whistleblowing Intentions}

Gray (2004) explained that whistleblowers can get the attention of other people. This means that whistleblowers can give a signal whether an action must be stopped, such as when a whistleblower reports to stop a behavior that is considered as harmful to his company. In whistleblowing, a whistleblower also may suffer a risk of responses of an organization especially from the highest leadership. Data from a sample of 3,288 government employees, it shows that 53 percent of them were inactive, and they did not report the frauds because there was no sufficient response from organizations to perform follow up action related to report of frauds (Taylor \& Curtis, 2013).

Whistleblowers should have legal protection from dismissals or inhuman actions as a form of retaliation, after the whistleblowers report internally to the executive management, or externally to the press or law enforcement authorities. Whistleblowers usually express their concerns externally only after they have not received internal corrective responses (Jalil, 2014). Whistleblowing is sometimes seen as unethical action, although there are those who think that whistleblowing is a form of action that can improve the security of an organization, and even deserves appreciation (Putri, 2012).

Whistleblowing has an important role in the progress of an organization because whistleblowers act for the sake of long term missions and success of their organization (Kassa \& Utami, 2019). Whistleblowers and public in general have a right for a better legal protection. The absence of organizational response has become the major disincentive for employees who try to protect the public by revealing frauds. Meng and Fook (2011) explained that legal protection for whistleblowers influences whistleblowing intentions in an organization. Thus, the intention to conduct a whistleblowing is higher if the whistleblower gets a legal protection. Thus a hypothesis can be formulated as follows:

$\mathbf{H}_{2}$ : Subjects in condition of receiving an organizational response will have a higher whistleblowing intention than subjects in condition of not receiving an organizational response

\section{The Relationship Between Reporting Systems and Organizational Responses with Whistleblowing Intentions}

Keenan (2000) explained the perceptions of organizational support are instrumental in the decision of whistleblowing, and in the determination of which reporting channel (internal or external) should be used for reporting the wrongdoing. Alleyne et al., (2013) explained the importance of perceived organizational support for individuals to report unethical actions. This is based on social exchange theory, an organization that treats employees well creates a sense of obligation in employees, so that in order to fulfil feelings of obligation, employees respond in a way that benefits the organization. The empirical evidence suggests that organizational culture can play a decisive role in driving the whistleblowing process, as management's response is a major factor that can influence the potential whistleblower's decision to act (Alleyne, Charles-Soverall, Broome, \& Pierce, 2017). An employee who is aware of frauds in the management of his organization, he has two choices, namely, to report or not to report frauds because, in general, in any situations which is in situation of reporting or no reporting, he will consider that he is under pressure (Nugraha, 2017). When an individual wants to report frauds in his organization, he must have a strong desire or intention to take action. Hanif dan Odiatma (2017) explained that individuals will consider whether a reporting system within an organization has been very effective to create responses. Marliza (2018) explained that employees who have high organizational commitment in themselves will emerge a sense of belonging so that he will not hesitate to do whistleblowing because he believes these actions will protect his organization from destruction. Anonymous channel systems will increase whistleblowing intention depending on the response of the organization in following up on fraud. Thus, there is an interaction between organizational responses and anonymous channel of interest in increasing whistleblowing intention. Thus a hypothesis can be formulated as follows. 
$\mathbf{H}_{3}$ : There is an interaction between reporting systems and organization's responses with whistleblowing intentions.

\section{Research Methods}

This research uses a design of $2 \times 2$ experiments between subjects, with whistleblowing intention variable as an independent variable and reporting system and the organizational response toward whistleblowers as the dependent variable. The subjects in this study were Accounting students who took auditing courses. This study chose students as experimental subjects because students have a high level of concentration and have the ability to analyze cases properly (Carini, Hayek, Kuh, Kennedy, \& Ouimet, 2003). Students who took auditing courses were students at the second year of the second term. Students as the subjects in the experiments were considered that they understood the course of auditing, because this study was conducted at the end of the semester at two universities in Central Java. Differences in study sites did not affect whistleblowing intentions, because whistleblowing intentions originated from within individuals (Dozier \& Miceli, 1985).

Audit assignments in this study relate to the desire of employees to report frauds in their company where they work. By understanding the auditing course, students who acted as accountant staffs in a company would be able to analyze the assignments because the assignment had has been reviewed in the material of fraud in the auditing course. As an example of study that uses experiments with students as research subjects is the study that was conducted by Widi and Utami (2015) who examined whistleblowing.

\section{Experiment Tasks and Procedures}

Subjects were divided into 4 groups randomly based on the treatments of online reporting system, the offline reporting system, getting responses, and not getting responses from the organization. The design matrix of the study is explained in Table 1.

Table 1. Matrix of Research Experiment

\begin{tabular}{llcc}
\hline Whistleblowing Intention & \multicolumn{2}{c}{ Whistleblowing Reporting System } \\
\cline { 3 - 4 } & & Online & ffline \\
\hline Organizational Response & Yes & Group 1 & Group 2 \\
& No & Group 3 & Group 4 \\
\hline
\end{tabular}

In this study a subject acted as a financial staff of PT Toshiba who is making a year-end financial statement. One of the marketing staffs was asked for help from the financial staff to manipulate the sales results which would later be included in the year-end financial statement. But the financial staff was hesitant to commit the fraud. The subject who acted as an employee was faced with a request to commit fraud in the form of data manipulation Employees had the opportunity to report frauds to the leadership of their organization.

Subjects received online and offline reporting facilities, according to respective modules. Subjects who got the online reporting facility, they obtained an online reporting tool called the Whistleblowing System (WBS) of PT Toshiba. Subjects who received an anonymous reporting system reported frauds by meeting the company leaders directly, by telephone, or using letters addressed to company leaders. Subjects will also get a response from the company if the fraud can be proven, but if it cannot be proven then the company leader will not give a response to the reporters.

At the beginning of the audit assignment, subjects were divided into 4 groups randomly consisting of group 1 (online reporting system and a response), group 2 (offline reporting system and a response), group 3 (online reporting system and no response) and group 4 (offline reporting system and no response). In the experiment, subjects obtained different modules randomly and they got an 
explanation about the procedure of filling out of modules and explanation about information of each module. At the second stage, subjects were given time to fill out the complete data with the aim of demographics testing that might influence their decision making.

At the third stage, subjects were asked to answer some general questions about the knowledge of audit. Whistleblowing is one of audit materials that have been learned by subjects in their studies. At the fourth stage, subjects were given information about the profile of the company where they worked. Subjects acted as employees who are having an intention to report the manipulation of sales data through the existing systems and considering responses from the leadership of the company. Subjects then received five checking questions for manipulation related to their understanding about the tasks and their role as employees who were under consideration to make decisions. At the fifth stage, modules that contain answers would be collected. At the sixth stage, debriefing was held to restore subjects' condition to their initial states.

\section{Analysis Techniques}

The first stage is the testing of manipulation check, with the aim to find out who passed and who did not pass the manipulation check. Next is the descriptive subject testing and testing of the effectiveness of randomization using One Way Analysis of Variance (ANOVA). The purpose of randomization testing is to provide confidence that only manipulation that affects the subject's decision to do whistleblowing or not do whistleblowing because of differences in demographic characteristics. Randomization will be effective if there is no difference in the decision to do whistleblowing between subjects based on demographic characteristics. The testing of first and second hypothesis is processed using the Independent-Sample T-test. Testing of hypothesis three uses two-way Anova to see whether there is an interaction between two independent variables. A hypothesis is accepted if the probability is below 0.05 , which means that there is a significant difference in the subject's decision to do whistleblowing between the control group and the group that is being compared.

\section{Result and Discussion}

\section{Overview of Experiments}

Experiments were conducted at two universities in Central Java with students who were taking auditing course as research subjects. Subjects who received treatments and escaped the five manipulation questions on roles, assignments and manipulations were 73 students out of 88 students. The characteristics of each subject consist of four categories, namely, gender, age, grade point average, and semester. The profiles of subjects who have participated in this study are shown in Table 2.

Table 2. Subject Profiles

\begin{tabular}{lcr}
\hline Information Total & & Percentage \\
\hline Gender: & & \\
Female & 62 & $84,9 \%$ \\
Male & 11 & $15,1 \%$ \\
Age: & & \\
19-21 & 73 & $100 \%$ \\
Grade Point Average (GPA): & \\
$2,50-2,99$ & 1 & $1,4 \%$ \\
$3,00-3,50$ & 44 & $60.3 \%$ \\
$\geq 3,5$ & 28 & $38,3 \%$ \\
Semester: & & \\
$<5$ & 20 & $27,4 \%$ \\
$\geq 5$ & 53 & $72,6 \%$ \\
\hline
\end{tabular}


Table 2 provides information that there are 73 male and female subjects in this study. The majority of subjects in this study were studying for the second semester of the 2018/2019 school year where subjects were studying audit subject. It is calculated that 1 person has GPA in a range of 2.50 - 2.99; 44 people have GPA in a range of 3.00 - 3.50; while 28 people have GPA of more than 3.50. The average age of the subjects in this study was 19-21 years old.

In this study, the subjects acted as staffs of PT Toshiba financial accountant, whose task is to prepare financial reports that are accountable to the company's leaders. However, in compiling the report, there was an error made by the marketing staff, due to the failure to achieve sales target in that year, which it forced the marketing staff to manipulate the sales data. In this case, the marketing staff faced a dilemma of whether to keep the error or to make a fraud that in either of these choices the staff would be severe sanctions by his company according to the applicable regulation. At the beginning of the assignment, a subject was given a checking of manipulation by giving an assessment of whether the subject would report a fraud if there was a manipulation of sales data in that year according to the provided online and offline reporting systems and the responses from the company to the subject.

\section{Checking of Manipulation}

Checking of manipulation on reporting systems and organizational responses was done by viewing the results of 5 questions given in the manipulation. Checking of manipulation on reporting systems and organizational responses were conducted to determine whether subjects are qualified for the testing. Subjects who had passed the 5 questions of pre-test and testing of information about the company profile were 88 students. After manipulation checking, 15 students did not pass the test, and as a result, the data that were processed were 73. Manipulation checking was done by looking at the number of questions answered correctly by the subjects.

In conditions related to questions of manipulation are: offering of online or offline reporting system; cases of fraud that occurred in the organization; the perpetrators of fraud, the reporting systems are used; the background of subject that decided to report or not to report; about the time chose by subjects to report and about which subject who decided to make or not to make a report. From the 5 manipulation questions that were given, 73 subjects passed the manipulation check (subjects who can answer three or more of the three manipulation questions correctly). Based on the results of checking manipulation, it can be concluded that all subjects had received manipulation treatments based on the reporting systems and organizational responses. Based on these results, the experiment can be continued with the next test.

\section{Testing of Randomization}

Table 3. One Way ANOVA Test Results

\begin{tabular}{lccc}
\hline & Mean Square & Sig. & Information \\
\hline Gender: & & & \\
Between Groups & 0,194 & 0,176 & No Influence \\
Within Groups & 0,131 & & \\
Age: & 0,342 & 0,778 & No Influence \\
Between Groups & 0,555 & & \\
Within Groups & & & \\
Grade Point Average (GPA): & 0,281 & 0,039 & No Influence \\
Between Groups & 0,262 & & \\
Within Groups & & & \\
Semester: & 0,286 & 0,165 & No Influence \\
Between Groups & 0,190 & & \\
Within Groups & & & \\
\hline
\end{tabular}


Before testing the hypothesis, a randomization test of the demographic characteristics of the subjects' profiles was implemented using the One-Way Analysis of Variance (ANOVA) Test. This test was conducted to determine whether demographic factors affect decision making. The characteristics of subjects consist of four categories, namely, gender, age, Grade Point Average (GPA), and semester. All of four categories have a significance level (Sig.) greater than alpha (0.05), so it can be concluded that the four indicators did not influence the assessment of whistleblowing. Randomization was thus said to be effective because only treatment that can influence the subject's reporting decisions.

\section{The Relationship of Reporting Systems with Whistleblowing Intentions}

Hypothesis 1 of this study states that subjects that use online reporting system will have higher whistleblowing intentions than subjects that use offline reporting system. Testing was done using Sample Test T-test with one population consisting of group 1 and group 2 that obtained an online reporting system treatment while group 3 and group 4 that obtained an offline reporting system treatment.

Table 4. Hypothesis Testing Results 1

\begin{tabular}{ccccc}
\hline & Mean & Std Deviation & T & Sig. (2-tailed) \\
\hline Reporting System & & & & \\
Online & 74,50 & 24,59 & 2,646 & \\
Offline & 56,45 & 25,99 & 2,572 & 0,002 \\
\hline
\end{tabular}

Table 4 explains that the average for potential whistleblowing in the treatment of online reporting systems is 74.50 while in the treatment of offline reporting systems is 56.45 . Statistical test results show that the value of Sig. (2-tailed) in equal variances that is not assumed in the t-test for Equality of Means is 0.002, which is smaller than alpha (0.05), so it can be concluded that it is significant at the $5 \%$ probability level. The test results show that whistleblowing intention is higher in the condition of online reporting system when than whistleblowing intention in the condition of offline reporting system.

When an online reporting system was provided, employees believed that there was a protection facility they received threats due to their reporting of frauds in the organization. The online reporting facility is an important factor because it is believed to be able to protect a reporter's identity and make employees more comfortable and easier in submitting reports of known fraud in their organization. The online reporting facility that was provided by the organization, employees believed that their whistleblowing actions were supported and justified by the leadership of the organization. Employees were then motivated to show certain behaviors. Employees can be then sure that whistleblowing through an online reporting channel is the right action to prevent frauds.

The results of this hypothesis test support the results of research found by Lowry et al. (2012) which shows that many parties have implemented online whistleblowing reporting systems. The results of this hypothesis test also support the research of Lowry et al. (2013) which shows that an anonymous online reporting system can increase employees' intention to do whistleblowing. The existence of an online reporting facility does not need a large amount of money and time. Besides, an online reporting facility can overcome the travel distance needed by whistleblowers to report frauds because they only need an internet connected communication device to do whistleblowing. In addition to the capability of online reporting facility to provide convenience for whistleblowers to report frauds, it also guarantees the confidentiality of the whistleblowers' identities from the threat of retaliation. Therefore, whistleblowers will feel safer and free in submitting reports of fraud that they find.

Also in other organizations, if an employee is aware that a fraud occurs in his company, an online reporting system can encourage his intention to do whistleblowing (Kaplan \& Schultz, 
2007). In fact, an online reporting system is easy to use and fast to report frauds and it can secure the identity of reporters, and thus it can improve one's intention to do whistleblowing compared to offline reporting system of which it takes a long time for someone to report a fraud.

\section{The Relationship of Organizational Responses with Whistleblowing Intentions}

Hypothesis 2 in this study claims that subjects that in the condition of getting of organizational responses will have higher whistleblowing intentions than subjects in the condition of not getting of offline reporting system. Testing was done using Sample Test T-test with one independent population consisting of group 1 and group 3 who obtained organizational responses while group 2 and group 4 did not obtain organizational responses.

Table 5. Hypothesis Testing Results 2

\begin{tabular}{ccccc}
\hline & Mean & Std Deviation & T & Sig. (2-tailed) \\
\hline $\begin{array}{c}\text { Organizational } \\
\text { Response }\end{array}$ & & & \\
Yes & 77,17 & 19,39 & 5,594 & \\
No & 46,66 & 27,03 & 5,319 & 0,024 \\
\hline
\end{tabular}

Table 5 explains that the potential for whistleblowing in the treatment of obtaining of organizational responses, on average is 77.17 while in the treatment of not obtaining organizational responses is 46.66. The statistical test results explain the value is 0.024 for Sig. (2-tailed) which equal variances are not assumed in the t-test for Equality of Means, which is smaller than alpha (0.05). Thus, it can be concluded that whistleblowing is significantly greater in the condition of obtaining organizational responses compared to the potential of whistleblowing in the condition of not obtaining organization responses.

When employees had whistleblowing systems and responses from the leadership of their company, they believed that those responses were can give the legal guarantee regarding the confidentiality of their identities, which in turn those responses can motivate employees to do whistleblowing. With a reporting system that is accompanied with responds, employees can be confident that their whistleblowing actions are supported and justified by their organization, thus creating social pressure to display certain behaviors. Employees can then be sure that whistleblowing that is supported with responses and guarantees is the right way to prevent frauds from occurring.

The results of this hypothesis test support the research results of Taylor and Curtis (2013) and Meng and Fook (2011) showing that the response to whistleblowers can motivate and encourage their intentions to do whistleblowing. Employees will have courage to step forward to do whistleblowing when they obtain organizational responses from the leadership of their organization (Gray, 2004). Whistleblower will feel safe and free from all forms of threats given by those who commit frauds such as dismissal, demotion or other threats when whistleblowers get responses from leaders of organization. Thus, when a fraud occurs in an organization, whistleblowers will do whistleblowing.

\section{The Interaction Between Reporting Systems and Organizational Responses with Whistleblowing Intentions}

The results of Hypothesis 1 and Hypothesis 2 explain that the two independent variables, namely, reporting systems and organizational responses show significant results affecting whistleblowing intentions. Hypothesis 3 states that there are interactions between the two independent variables, namely, reporting systems and organizational responses with whistleblowing intentions. To test these hypotheses, Two Way Anova testing can be used to compare the mean difference among groups based on two independent variables. 
Table 6. Test of Between Subject Effects on Hypothesis 3 Data

\begin{tabular}{lrc}
\hline \multicolumn{1}{c}{ Source } & Mean Square & \multicolumn{1}{c}{ Sig. } \\
\hline Corrected Model & 3032,501 & 0,000 \\
Intercept & 234221,704 & 0,000 \\
Reporting System & 6065,454 & 0,000 \\
Organizational Response & 6178,930 & 0,000 \\
Reporting System* Organizational Response & 666,430 & 0,033 \\
\hline
\end{tabular}

Table 6 shows that the Sig. Corrected Model of 0,000 value which means it is smaller than alpha (0.05) and thus it indicates that all independent variables, namely, reporting system (SP) and organizational response (RO) as well as the interaction between reporting systems and organizational responses ( $\mathrm{SP} * \mathrm{RO})$ jointly influence significantly towards the dependent variables, and as a result, this model can be said as valid. The Intercept shows the value of Sig. 0.000 that is smaller than alpha (0.05), which means the value of changes in the dependent variables without the need of influence from the independent variables, which means that without the influence of the independent variables, the dependent variables can be changed in value.

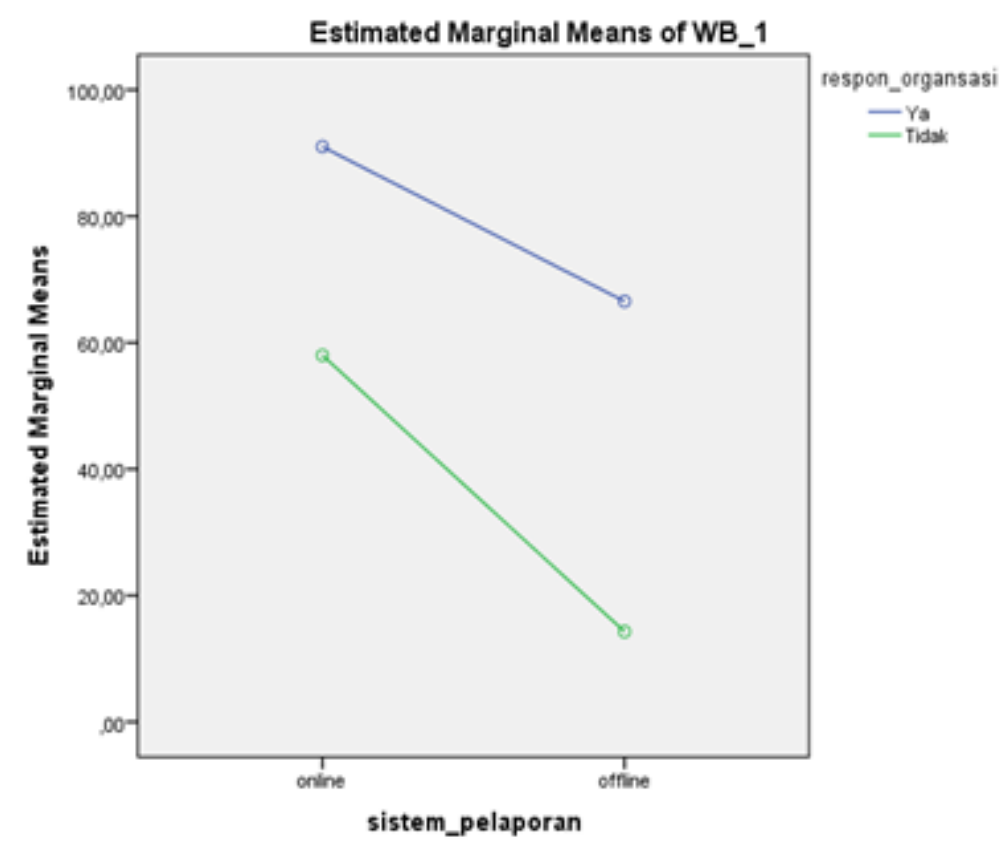

Figure 1. The Plot Diagram of Reporting System Interaction and Organizational Responses

The variables of reporting systems and the organizational responses have been interpreted significantly influence the whistleblowing intentions in this model. The reporting system shows a significance value of 0,000 which is less than alpha (0.05) and organizational responses show a significance value of 0,000 which is less than alpha (0.05). Next, the interaction of reporting systems and organizational responses show a significance value of 0.033 which is smaller than alpha $(0.05)$, which means that the interaction between reporting systems and the organizational responses in this model significantly influences the increase of whistleblowing intentions. The interaction between reporting systems and organizational responses is depicted in Figure 1.

Figure 1 shows that the first group in the condition of obtaining an online reporting system and organizational response was at the point of estimated marginal means at the value of more than 80.00 and has a higher position compared to the other three conditions. The second group in the condition of obtaining an offline reporting system and organizational response came in second place at the point of estimated marginal means at the value more than 60.00 . The third group 
consisting individuals in the condition of obtaining an online reporting system and not obtaining organizational response was at the third position with the point of estimated marginal means of more than 40.00. Meanwhile, the fourth group that has the potential level of whistleblowing intentions for individuals who obtained an offline reporting system and who did not obtain an organizational response was at the lowest point of estimated marginal means i.e. at under 20.00 compared to the other three conditions.

An interaction was found between whistleblowing reporting systems and organizational responses with whistleblowing intentions, because especially the online reporting system is very effective in eradicating frauds and can increase whistleblower intentions to report (Kaplan \& Schultz, 2007; Lowry et al., 2013). Organizational response that is given to whistleblowers will also be an important factor in encouraging their intentions to dismantle frauds (Taylor \& Curtis, 2013), so that whistleblowers' intention to combat fraud can be realized effectively. When whistleblowers have a will to change an organization to be free from frauds, they will report the frauds, though they know that they may get the risks and negative impacts in the future due to their whistleblowing action.

\section{Conclusion}

This study examines the effectiveness of reporting systems and organizational responses toward the intention to conduct whistleblowing using an experimental study. The analysis shows that, first, reporting systems significantly influence whistleblowing intentions. If a whistleblower obtains an online fraud reporting system, it makes his intention to be high to conduct whistleblowing. The existence of an online reporting system makes easy for whistleblower to report frauds and this system can secure the confidentiality of whistleblowers' identities so that in turn whistleblowers' intention to do whistleblowing will be higher. Meantime, whistleblowers that obtain an offline reporting system by notifying the fraud directly to the leadership of organization and holding a meeting to discuss the occurring frauds in their organizations, their intention will be potentially reduced to conduct whistleblowing. Thus, the potential for someone to do whistleblowing is greater when he obtains an online reporting system compared to when someone in the condition to use an offline reporting system.

Second, organizational responses have significant effects on whistleblowing intentions. The more responses to the employees of PT Toshiba, the more convincing of employees' intention to do whistleblowing when an error happens that is not in accordance with the provisions of the company, and a result, various forms of frauds within the company can be tackled. Conversely, the lack of organizational responses will reduce the intention of P'T Toshiba employees to conduct whistleblowing.

Third, there is an interaction between reporting systems and organizational responses with whistleblowing intentions. This happens because whistleblowing intention may come from within an individual and not from external influences. When someone has a will to fix errors or frauds in his organization, he will report it even though he knows that he may receive negative impacts immediately or later.

\section{References}

AICPA. (2007). American Institute of Certified Public Accountants. New York.

Alleyne, P., Charles-Soverall, W., Broome, T., \& Pierce, A. (2017). Perceptions, predictors and consequences of whistleblowing among accounting employees in Barbados. Meditari Accountancy Research, 25(2), 241-267.

Alleyne, P., Hudaib, M., \& Pike, R. (2013). Towards a conceptual model of whistle-blowing intentions among external auditors. The British Accounting Review, 45(1), 10-23.

Arismaya, A. D., \& Utami, I. (2019). Facts, causes and corruption prevention: Evidence In Indonesian ministries. Journal of Contemporary Accounting, 1(2), 95-106. 
https://doi.org/10.20885/jca.vol1.iss2.art3

Ayers, S., \& Kaplan, S. E. (2005). Wrongdoing by consultants: An examination of employees' reporting intentions. Journal of Business Ethics, 57(2), 121-137.

https://doi.org/10.1007/s10551-004-4600-0

Brief, A. P., \& Motowidlo, S. J. (1986). Prosocial organizational behaviors. The Academy of Management Review, 11(4), 710-725. https://doi.org/10.2307/258391

Brink, A. G., Lowe, D. J., \& Victoravich, L. M. (2013). The effect of evidence strength and internal rewards on intentions to report fraud in the dodd-frank regulatory environment. Auditing, 32(3), 87-104. https://doi.org/10.2308/ajpt-50449

Carini, R. M., Hayek, J. C., Kuh, G. D., Kennedy, J. M., \& Ouimet, J. A. (2003). College student responses to web and paper surveys: Does mode matter. Research in Higher Education, 44(1), 1-19. https://doi.org/10.1023/A:1021363527731

Chiu, R. K. (2003). Ethical judgment and whistleblowing intention: Examining the moderating role of locus of control. Journal of Business Ethics, 43(1-2), 65-74. https://doi.org/10.1023/A:1022911215204

Dozier, J. B., \& Miceli, M. P. (1985). Potential predictors of whistle-blowing: A prosocial behavior perspective. Academy of Management Review, 10(4), 823-836. https://doi.org/10.5465/AMR.1985.4279105

Gray, J. A. (2004). The scope of whistleblower protection in the state of Maryland : A comprehensive statute is needed. University of Baltimore Law Review, 33(2), 225-256.

Hanif, R. A., \& Odiatma, F. (2017). Pengaruh personal cost reporting, status wrong doer dan tingkat keseriusan kesalahan terhadap whistleblowing intention. Jurnal Akuntansi Kenangan Dan Bisnis, 10(1), 11-20.

Jalil, F. Y. (2014). Pengaruh komitmen profesional dan sosialisasi antisipatif mahasiswa Audit terhadap perilaku whistleblowing. Jurnal Bisnis Dan Manajemen, 4(2), 198-209.

Kaplan, S. E., \& Schultz, J. J. (2007). Intentions to report questionable acts: An examination of the influence of anonymous reporting channel, internal audit quality, and setting. Journal of Business Ethics, 71(2), 109-124. https://doi.org/10.1007/s10551-006-0021-6

Kassa, S., \& Utami, I. (2019). Whistleblowing, ethical dilemma and professional commitment in village fund administration. Religación. Revista de Ciencias Sociales y Humanidades, 4(17), 682-691.

Keenan, J. P. (1990). Upper-level managers and whistleblowing: determinants of perceptions of company encouragement and information about where to blow the whistle. Journal of Business and Psychology, 5(2), 223-235. https://doi.org/10.1007/BF01014334

Keenan, J. P. (2000). Blowing the whistle on less serious forms of fraud: A study of executives and managers. Employee Responsibilities and Rights Journal, 12(4), 199-217. https://doi.org/10.1023/A:1013015926299

Lestari, R., \& Yaya, R. (2017). Whistleblowing dan faktor-faktor yang memengaruhi niat melaksanakannya oleh aparatur sipil negara. Jurnal Akuntansi Keuangan Dan Bisnis, 21(3), 336-350. https://doi.org/10.24912/ja.v21i3.265

Li, J., Zhu, L., \& Gummerum, M. (2014). The relationship between moral judgement and cooperation in children with high-functioning autism (Scientifitc Reports 4 No. 4314). Plymouth. https://doi.org/10.1038/srep04314

Lowry, P. B., Moody, G. D., Galletta, D. F., \& Vance, A. (2013). The drivers in the use of online whistle-blowing reporting systems. Journal of Management Information Systems, 30(1), 153190. https://doi.org/10.2753/MIS0742-1222300105 
Lowry, P. B., Rouibah, K., Moody, G., \& Siponen, M. (2012). Towards a cross-cultural model of online whistle-blowing systems use. In Proceedings - Pacific Asia Conference on Information Systems. Ho Chi Minh, Vietnam: Association For Information System.

Marliza, R. (2018). Komitmen profesional, lingkungan etika, sifat machiavellian dan personal cost terhadap intensi whistleblowing dengan retaliasi sebagai variabel moderating: Studi empiris pada perusahaaan perbankan yang berada di kota Pekanbaru. Jurnal Akuntansi Fakultas Ekonomi, 6(1), 1-20.

Meng, T. P., \& Fook, O. S. (2011). Comparative analysis of whistleblower protection legislations in England, USA and Malaysia. African Journal of Business Management, 5(2), 11246-11255.

Near, J. P., \& Miceli, M. P. (1995). Effective-whistle blowing. Academy of Management Review, 20(3), 679-708.

Near, J. P., \& Miceli, M. P. (2016). After the wrongdoing: What managers should know about whistleblowing. Business Horizons, 59(1), 105-114. https://doi.org/10.1016/j.bushor.2015.09.007

Nugraha, T. (2017). Pengaruh komitmen profesional, lingkungan etika, sifat machiavellian dan personal cost terhadap intensi whistleblowing dengan retaliasi sebagai variabel moderating: Studi empiris pada perusahaaan perbankan yang berada di kota Pekanbaru. Jurnal Online Mahasiswa Fakultas Ekonomi, 4(1), 2030-2044.

Nurhidayat, I., \& Kusumasari, B. (2018). Strengthening the effectiveness of whistleblowing system a study for the implementation of anti- corruption policy in Indonesia. Journal of Financial Crime, 25(1), 140-154. https:// doi.org/10.1108/JFC-11-2016-0069

Putri, C. M. (2012). Pengujian keefektifan jalur pelaporan pada structural model dan reward model dalam mendorong whistleblowing: Pendekatan eksperimen. In Simposium Nasional Akuntansi 15. Banjarmasin.

Sagara, Y. (2013). Profesionalisme internal auditor dan intensi melakukan whistleblowing. Jurnal Liquidity, 2(1), 34-44.

Salsabil, S. M., Utami, I., \& Hapsari, A. N. S. (2019). Fraud dan whistleblowing: Tinjauan pengelolaan dana organisasi kemahasiswaan. Jurnal Akuntansi Bisnis, 12(1), 64-76.

Setyawati, I., Ardiyani, K., \& Sutrisno, R. C. (2015). Faktor-faktor yang mempengaruhi niat untuk melakukan whistleblowing internal. Jurnal Ekonomi Dan Bisnis, 17(2), 22-33.

Smith, H. J., Keil, M., \& Depledge, G. (2001). Keeping mum as the project goes under: Toward an explanatory model. Journal of Management Information Systems, 18(2), 189-227. https://doi.org/10.1080/07421222.2001.11045677

Sunaryo, K., Astuti, S., \& Zuhrohtun, Z. (2019). The role of risk management and good governance to detect fraud financial reporting. Journal of Contemporary Accounting, 1(1), 3846. https://doi.org/10.20885/jca.vol1.iss1.art4

Taylor, E. Z., \& Curtis, M. B. (2013). Whistleblowing in audit firms: Organizational response and power distance. Behavioral Research in Accounting, 25(2), 21-43.

Utami, I., Jori, A., \& Hapsari, A. N. S. (2017). Sudikah akuntan mengungkap aib kecurangan? Jurnal Akuntansi Multiparadigma, 8(3), 458-469.

Widi, E., \& Utami, I. (2015). Studi ekperimental tekanan ketaatan dan personal cost : Dampaknya terhadap whistleblowing. Jurnal Akuntansi Dan Bisnis, 15(2), 106-119.

Zarefar, A., \& Arfan, T. (2017). Efektivitas whistleblowing system internal. Jurnal Akuntansi Keuangan Dan Bisnis, 10(2), 25-33. 